\title{
Response of sea-ice microbial communities to environmental disturbance: an in situ transplant experiment in the Antarctic
}

\author{
Andrew Martin ${ }^{1,2, *}$, Marti J. Anderson ${ }^{3}$, Chris Thorn ${ }^{1}$, Simon K. Davy ${ }^{1}$, \\ Ken G. Ryan ${ }^{1}$ \\ ${ }^{1}$ School of Biological Sciences, Victoria University of Wellington, Wellington 6140, New Zealand \\ ${ }^{2}$ Institute of Marine and Antarctic Studies, University of Tasmania, Hobart 7001, Australia \\ ${ }^{3}$ Institute of Information and Mathematical Sciences, Massey University, Albany 0632, New Zealand
}

\begin{abstract}
Sea-ice microbial communities are integral to primary and secondary production in icecovered regions of the Southern Ocean, but few studies have characterised the heterogeneity of microbes within the ice or determined whether habitat variability influences community dynamics. We examined the response of sea-ice microbes to key physicochemical variables by conducting an $18 \mathrm{~d}$ reciprocal transplant experiment within Antarctic fast-ice. A series of ice cores were extracted from $2.6 \mathrm{~m}$ annual ice and reinserted upside down to expose resident microbial assemblages to significantly different light, temperature and salinity regimes. The abundance and community composition of bacteria, microalgae and protozoa was subsequently determined within 3 sections of each core (top, middle and bottom) and compared with experimental controls. Results demonstrate that iceassociated microbes are finely attuned to discrete microhabitats within the sea-ice matrix. Positive growth and a shift in community composition was observed for microalgae moved from the top to the bottom of the ice, but significant bleaching of photosynthetic pigments resulted in zero net growth for bottom-ice communities exposed to the surface. Although bacteria may have been less vulnerable to initial change in their microenvironment, there was no significant increase in the average abundance of cells at either end of the flipped cores after $18 \mathrm{~d}$, despite a presumed increase in algal-derived dissolved organic matter. This suggests a significant lag in the response time of bacteria to available growth substrates and a temporary 'malfunction' of the microbial loop.
\end{abstract}

KEY WORDS: Antarctica $\cdot$ Sea-ice $\cdot$ Microbes $\cdot$ DGGE $\cdot$ Transplant experiment $\cdot$ Microbial loop

\section{INTRODUCTION}

A mechanistic understanding of productivity and trophodynamics in the Antarctic sea-ice ecosystem poses a significant challenge to microbial ecologists. This is due not only to the complex suite of physicochemical variables that stratify the ice matrix (Arrigo \& Sullivan 1992, Ackley \& Sullivan 1994, McMinn et al. 1999a), but also to the concomitant task of linking spatial and temporal variability in annual sea-ice formation with the taxonomic diversity and functional capabilities of ice-associated microbes (Mock \& Thomas 2005, Murray \& Grzymski 2007).
During initial ice formation in the austral autumn, planktonic organisms are scavenged from the water column and, as the ice develops, these microbes are concentrated into a closed or semi-closed labyrinth of brine channels and pores that vary in size from micrometers to several millimetres (Garrison 1991, Thomas \& Dieckmann 2002, Arrigo \& Thomas 2004). Sea-ice is characterised by steep vertical gradients in light, temperature, salinity and nutrient concentration and, although the initial inoculum comprises a diverse group of mixed species, only a subset possesses the physiological and biochemical mechanisms that enable colonisation of the ice matrix (Arrigo \& Sullivan 1992, Mc- 
Minn et al. 1999a, Deming 2002, Thomas \& Dieckmann 2002). Despite this strong selection process, discrete assemblages of psychrophilic organisms, including bacteria, microalgae and protozoa, are present throughout the ice habitat (Garrison 1991, Archer et al. 1996, Fritsen et al. 2001, Gowing et al. 2004, Garrison et al. 2005) which can cover up to 20 million $\mathrm{km}^{2}$ of the Southern Ocean during the austral winter (Horner 1985).

The most conspicuous ice-bound organisms are microalgae, and research efforts have historically focused on the composition, physiology and ecology of the pennate diatoms that dominate fast-ice assemblages (e.g. Kottmeier \& Sullivan 1988, Garrison 1991, Arrigo et al. 1998, McMinn et al. 2000, Ryan et al. 2002). Sea-ice microalgae contribute between 10 and $28 \%$ of the total primary production in ice-covered regions of the Southern Ocean (Legendre et al. 1992, Arrigo et al.1997); over $90 \%$ of this biogenic carbon is produced within first-year ice and approximately $60 \%$ is produced in the austral spring, NovemberDecember (Arrigo \& Thomas 2004).

During the annual development of the microbial community, photosynthetic metabolism is often spatially and temporally correlated with the growth of heterotrophic bacteria (McGrath Grossi et al. 1984, Delille et al. 1995, Stewart \& Fritsen 2004). Secondary bacterial production is stimulated by the concentration of dissolved organic matter (DOM) within the ice and can reach up to $10 \%$ of primary production. The release of photosynthate and the production of extracellular polysaccharides (EPS) by microalgae (McGrath Grossi et al. 1984, Krembs et al. 2002, Meiners et al. 2004), as well as the rupture and degradation of algal cells associated with protozoan grazing (Günther et al. 1999), contribute significantly to the pool of DOM available for bacterial metabolism. In return, bacteria are thought to provide recycled inorganic nutrients such as phosphate, nitrate and ammonia and/or vitamins that are required for continued algal growth (Kottmeier et al. 1987, Kottmeier \& Sullivan 1990, Archer et al. 1996). Co-variation between the autotrophic and heterotrophic biomass is integral to the microbial loop (Azam et al. 1991, Azam \& Malfatti 2007), but this metabolic pathway is complicated by factors such as variability in sea-ice conditions, relative age of the ice, synergistic effects of DOM concentration and in situ temperature (Helmke \& Weyland 1995, Pomeroy \& Wiebe 2001, Thomas et al. 2001, Stewart \& Fritsen 2004), as well as the potential for microalgae to release bactericidal and/or bacteriostatic compounds (Monfort et al. 2000, Mock \& Thomas 2005, Pusceddu et al. 2009).

The links to higher trophic levels within the microbial loop are also complex. The consumption of bacteria by protozoa such as flagellates and ciliates may cycle as much as 20 to $30 \%$ of the ice-bound primary production to higher trophic levels (Delille et al. 2002, Staley et al. 2002), but the exact relationships between these organisms and rates of carbon transfer are not well defined (Archer et al. 1996, Stewart \& Fritsen 2004, Fiala et al. 2006). However, the microscopic fraction of the sea-ice community is known to be a concentrated food source which is crucial for the winter survival of crustaceous zooplankton such as the Antarctic krill Euphausia superba (Daly 1990, Kottmeier \& Sullivan 1990), and ice-associated microbes are likely to provide inocula for bloom events at the receding ice edge in the austral summer (Kottmeier \& Sullivan 1988, Giesenhagen et al. 1999, Lizotte 2001, Arrigo \& Thomas 2004).

Relatively few studies have characterised the vertical heterogeneity of the microbial community within Antarctic sea-ice (but see Archer et al. 1996, Delille et al. 2002, Garrison et al. 2005) or examined how physicochemical variables influence either in situ production or community composition (but see Grossmann \& Gleitz 1993, McMinn et al. 2000). In contrast, the microbial response to in vitro stimuli has been well characterised from melted ice cores and extracted brine (e.g. Ryan et al. 2004, Ralph et al. 2007, Martin et al. 2008, 2009). Unfortunately, this process destroys the internal micro-environment within the ice and homogenises the spatial arrangement of both microbes and DOM, which may influence microbial activity (Giesenhagen et al. 1999, Junge et al. 2001, Martin et al. 2009).

In the present study, a reciprocal transplant experiment was used to examine the in situ response of a seaice microbial community to significantly different microhabitats with respect to light, temperature, salinity and the availability of DOM. A series of ice cores was extracted from annual fast-ice in Terra Nova Bay, Antarctica, and reinserted back into the ice matrix upside down. The relative abundance and community composition of the bacteria, microalgae and protozoa present within the ice was determined after a period of $18 \mathrm{~d}$ (the duration of the time spent in the field), by reference to appropriate control treatments.

\section{MATERIALS AND METHODS}

Sampling. Sea-ice microbes were extracted on 2 occasions from $2.6 \mathrm{~m}$ fast-ice during the austral spring of 2006 at Terra Nova Bay, Antarctica $\left(74^{\circ} 38^{\prime} \mathrm{S}\right.$,

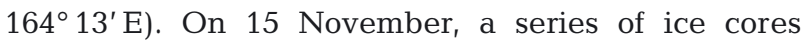
(130 mm diameter, $2.6 \mathrm{~m}$ length) was drilled within a 3 m radius using a Kovacs ice corer. To minimise light shock, ice cores were removed under a black sheet. Of the 9 extracted cores, 3 were immediately reinserted upside down (flipped) to provide the experimental treatment, 3 were replaced in their original orientation 
to control for the process of core removal and shearing of the ice (disturbed control) and 3 were used to establish an initial baseline of microbial abundance and diversity (time zero, $t_{0}$ ). The exact position of each reinserted core was marked precisely. After $18 \mathrm{~d}$, the flipped and disturbed control ice cores were carefully re-extracted from the sea-ice using the Kovacs corer. To control for potential change in the structure of microbial communities during the course of the experiment, 3 further cores were collected from the same region (undisturbed control).

Microbes were extracted by removing $100 \mathrm{~mm}$ long sections from each core at 3 distinct regions: top (0 to $0.1 \mathrm{~m})$, middle $(1.25$ to $1.35 \mathrm{~m})$ and bottom $(2.5$ to $2.6 \mathrm{~m})$. The central inner region of each core section was then removed $(40 \times 40 \times 100 \mathrm{~mm})$ using sterile techniques and melted into 3 times the volume of $0.22 \mu \mathrm{m}$-filtered seawater $\left(35 \%,-1.8^{\circ} \mathrm{C}\right)$ under low light $\left(<1 \mu \mathrm{mol}\right.$ photons $\left.\mathrm{m}^{-2} \mathrm{~s}^{-1}\right)$ in sterile containers over a period of $12 \mathrm{~h}$ (Ryan et al. 2004).

Physical measurements. Photosynthetically active radiation (PAR) was measured by embedding 4 Photosynthetic Light Smart Sensors (Microdaq) within the ice at the following depths: surface, 0.5, 1.2 and $1.8 \mathrm{~m}$. Data were recorded at 5 min intervals and stored in a Micro Station Data Logger (Microdaq). In addition, occasional under-ice PAR measurements were made using a LiCor $2 \pi$ sensor. Temperature was measured using custom-made loggers that were calibrated to record every $20 \mathrm{~min}$ and positioned as follows: surface, $0.05,0.5,0.95,1.4,1.85,2.3 \mathrm{~m}$ and in the water column $(2.65 \mathrm{~m})$. Salinity was derived using the average temperature at each depth of interest with the conversion equation of Cox \& Weeks (1986).

Chlorophyll a (chl a). A 100 to $300 \mathrm{ml}$ subsample of each melted ice core section was filtered onto a $47 \mathrm{~mm}$ GF/F filter and extracted in $10 \mathrm{ml}$ of methanol for $12 \mathrm{~h}$ in the dark at $4^{\circ} \mathrm{C}$. Chl a was then measured on a digital fluorometer (Turner 10AU) using the acidification method of Evans et al. (1987).

Enumeration and identification of microalgae and protozoa. A $10 \mathrm{ml}$ subsample of each core section was fixed in $0.5 \%$ gluteraldehyde and stored at $4^{\circ} \mathrm{C}$ until return to New Zealand. A minimum of 200 cells per sample were identified and counted on a Zeiss inverted microscope using a specially designed settling chamber and phase contrast optics. Depending on the concentration of cells, this required examining between one and six $0.5 \mathrm{ml}$ aliquots for each core section.

Enumeration of bacteria. A $5 \mathrm{ml}$ subsample of each core section was fixed in $0.05 \%$ gluteraldehyde and stored frozen at $-20^{\circ} \mathrm{C}$ until return to New Zealand. Enumeration of bacterial cells was performed using a Becton Dickinson FACScan flow cytometer equipped with a $15 \mathrm{~mW}, 488 \mathrm{~nm}$, air-cooled argon ion laser and standard filter setup. Initial instrument calibration was performed using FACScomp software in conjunction with Becton Dickinson CaliBRITE reference beads. To avoid coincidence, samples were run at a medium flow rate with less than 1300 events per second. CellQuest software (Becton Dickinson) was used for all sample and data analyses. Samples were thawed and $500 \mu \mathrm{l}$ was diluted with $2 \mathrm{ml}$ of $0.22 \mu \mathrm{m}$-filtered deionised water (required for high salinity samples, but standardised across all samples) and stained with $2.5 \mu \mathrm{l}$ of SYTO 13 (Molecular Probes) for $10 \mathrm{~min}$ (in the dark at ambient temperature). TruCount beads (Beckton Dickinson) were added to each sample to accurately calculate the volume of sample analysed. Bacterial data were typically collected for 2 min (acquisition of 250 TruCount beads) and cell populations were identified from bivariate plots of green fluorescence (FL1) versus side scatter (SSC).

Nucleic acid extraction and PCR amplification of bacterial 16S rRNA genes. For the molecular analysis of bacterial populations, approximately $300 \mathrm{ml}$ of each melted core section was concentrated onto a $0.22 \mu \mathrm{m}-$ pore size $47 \mathrm{~mm}$ Millipore filter using vacuum filtration and stored at $-80^{\circ} \mathrm{C}$ until return to New Zealand. Sterile techniques were maintained throughout this procedure. Genomic DNA was extracted from the bacteria on each filter using a phenol/chloroform/ isoamyl alcohol solution and precipitated in ethanol as described by Schäfer \& Muyzer (2001). The extracted DNA was quantified with a NanoDrop spectrophotometer (Thermo Fisher Scientific) and stored at $-20^{\circ} \mathrm{C}$ until analysis. Primers 357F (CCT ACG GGA GGC AGC AG) and 518R (ATT ACC GCG GCT GCT GG) were used to amplify a $194 \mathrm{bp} 16 \mathrm{~S}$ rRNA fragment targeting the V3 region (Murray et al. 1996). An additional GC-rich sequence of 40 nucleotides (GCclamp) was added to the $5^{\prime}$ end of primer $357 \mathrm{~F}$. PCR amplifications were performed using illustra PuReTaq Ready-To-Go PCR beads (GE Healthcare) with 1 to $3 \mu \mathrm{l}$ of DNA template (final reaction volume $25 \mu \mathrm{l}$ ). Temperature cycling was performed using an Eppendorf Thermal Cycler using the following conditions: initial denaturation at $94^{\circ} \mathrm{C}$ for $5 \mathrm{~min} ; 10$ touchdown cycles of denaturation (at $94^{\circ} \mathrm{C}$ for $1 \mathrm{~min}$ ), annealing (for $1 \mathrm{~min}, 65$ to $55^{\circ} \mathrm{C}$ decreasing $1^{\circ} \mathrm{C}$ each min) and extension (at $72^{\circ} \mathrm{C}$ for $3 \mathrm{~min}$ ); 20 standard cycles (denaturing at $94^{\circ} \mathrm{C}$ for $1 \mathrm{~min}$, annealing at $55^{\circ} \mathrm{C}$ for $1 \mathrm{~min}$ and extension at $72^{\circ} \mathrm{C}$ for $3 \mathrm{~min}$ ); and a final extension at $72^{\circ} \mathrm{C}$ for 5 min. PCR products were quantified by agarose gel electrophoresis using the Hyperladder I molecular size standard (Bioline).

Denaturing gradient gel electrophoresis (DGGE) analysis of 16S rRNA gene fragments. DGGE was performed using a D-Code ${ }^{\mathrm{TM}}$ Universal Mutation Detection System (Bio-Rad). Approximately $500 \mathrm{ng}$ of PCR 
product from each sample was loaded on a $8 \%(\mathrm{w} / \mathrm{v})$ polyacrylamide gel (acrylamide and $\mathrm{N}, \mathrm{N}^{\prime}$-methylene bisacrylamide at a ratio of 37:1) with a denaturing gradient that ranged from 40 to $70 \%$ (where $100 \%$ is defined as $7 \mathrm{M}$ urea and $40 \%$ deionized formamide). Gels were run for $18 \mathrm{~h}$ at a constant voltage of $100 \mathrm{~V}$ at $60^{\circ} \mathrm{C}$ in $1 \times$ TAE buffer ( $40 \mathrm{mM}$ Tris [pH 7.4], $20 \mathrm{mM}$ sodium acetate, $1 \mathrm{mM}$ EDTA). Gels were subsequently stained with a 1:10 000 dilution of SYBR Gold (Molecular Probes) for $30 \mathrm{~min}$, rinsed and visualised under UV light. Cluster analysis of DGGE band patterns was performed using BioNumerics (Applied Maths). Patterns were compared using the Dice similarity coefficient and unpaired pair-wise grouping with mathematical averages (UPGMA) to generate dendrograms.

Sequencing and comparative sequence analysis. To obtain sequence information, 12 randomly selected bands were excised from DGGE gels using sterile razor blades and eluted in $500 \mu \mathrm{l}$ of PCR-grade water for $48 \mathrm{~h}$. A total of $2 \mu \mathrm{l}$ of the eluant was used for re-amplification with the original primer set. A portion of the PCR product of the second amplification was reanalysed by DGGE to verify the correct band position. PCR products were then purified using Exo-SAP IT (USB Corporation) and quantified in an agarose gel using the Hyperladder I molecular size standard (Bioline).

PCR products were sequenced using the BigDye terminator ready reaction cycle sequencing kit (Version 3.1) using both forward and reverse primers. Sequencing reactions were analysed on an ABI3730 Genetic Analyser and sequences were compared with the GenBank database using BLAST to obtain the closest bacterial matches. The partial environmental 16S rRNA gene sequences recovered in this study were deposited in the GenBank database under the following accession numbers: HQ609845 to HQ609856.

Data analysis. To examine changes in the relative abundance of microalgae, bacteria and the concentration of chl $a$ in core sections of the flipped treatments versus the controls, ANOVA was used to perform partitioning and a series of appropriate contrasts and comparisons. The limited number of protozoa observed in the present study were included with the microalgae for statistical analyses. The experimental design consisted of 2 factors: Treatment, a fixed factor with 4 levels (time zero, $t_{0}$; undisturbed control, $\mathrm{UC}_{i}$ disturbed control, DC; and flipped cores, F) and Section (Se), a fixed factor with 3 levels (top, $\mathrm{T}$; middle, $\mathrm{M}_{\text {; }}$ and bottom, B). Of particular interest was the contrast of flipped cores versus all other treatments, i.e. F versus $\left(t_{0}, \mathrm{UC}, \mathrm{DC}\right)$. The full partitioning included contrasts to examine effects of core removal (disturbance) and temporal effects. However, we expected the contrast $F$ versus $\left(t_{0}, \mathrm{UC}, \mathrm{DC}\right)$ to interact with the Section factor if effects of flipping were apparent. To clarify results in this event, post hoc contrasts were performed to compare specific sets of treatment combinations: (1) flipped top to bottom (T-B) versus top controls; (2) flipped top to bottom (T-B) versus bottom controls; (3) flipped bottom to top (B-T) versus top controls; (4) flipped bottom to top (B-T) versus bottom controls; and (5) flipped middle versus middle controls. The 3 univariate variables chl $a$, density of microalgae and density of bacterial cells were each log-transformed prior to analysis. Each test in the ANOVA partitioning was based on a random subset of 9999 permutations of the raw data (Manly 2006), while those for specific contrasts utilised all 220 available permutations. All permutation tests were done using the PERMANOVA+ add-on for PRIMER v6 (Clarke \& Gorley 2006, Anderson et al. 2008). Scatterplots and Pearson correlations were used to examine the potential relationship between the density of bacteria and microalgae in control treatment cores and (separately) in the flipped treatment using SIGMAPLOT (Version 8.0, SPSS).

For multivariate analysis, microalgal count data (including protozoa) were standardised by sample totals so that the relative abundance values were comparable across different cores. Standardised values ranged from zero to approximately 70 and were square-root-transformed to balance the relative contribution of variables on different scales (Clarke \& Green 1988, Clarke \& Warwick 2001). Multivariate analyses were performed on the basis of a dissimilarity matrix among ice cores (30 taxa, 36 core sections), obtained using the Bray-Curtis measure (Bray \& Curtis 1957). The rank dissimilarities in composition and relative abundance among the assemblages in different treatments were visualised using non-metric multi-dimensional scaling (NMDS) on the distances among centroids (in the Bray-Curtis space) from the $\mathrm{n}=3$ cores per treatment.

Permutational distance-based multivariate analysis of variance (PERMANOVA; Anderson 2001, McArdle $\&$ Anderson 2001) was used to analyse the full $(30 \times 36)$ resemblance matrix on the basis of the 2-way experimental design, including all appropriate contrasts, as described above for the univariate analyses. All multivariate analyses were performed using PERMANOVA+ for PRIMER v6.

Band patterns of bacterial phylotypes generated with DGGE were compared using the Dice (Sørensen) similarity measure. This measure is equivalent to the Bray-Curtis measure calculated on presence-absence data and, as such, measures the percent similarity among communities in terms of the composition of phylotypes only. This resemblance matrix was analysed using the same multivariate techniques (i.e. NMDS of distances among Treatment $\times$ Section centroids and PERMANOVA with contrasts), as described above for 
the microalgal community. Due to significant changes in bacterial community structure over the $18 \mathrm{~d}$ period (in comparisons of $t_{0}$ versus [UC, DC]; (results not shown), the $t_{0}$ samples were omitted from these analyses for clarity.

\section{RESULTS}

\section{Physical measurements}

Light, temperature and derived salinity were highly variable within the fast-ice at Terra Nova Bay (Fig. 1). Mean daily in situ temperatures ranged from $-7.12^{\circ} \mathrm{C}$ $(0.05 \mathrm{~m})$ to $-4.36^{\circ} \mathrm{C}(1.85 \mathrm{~m})$ and daily mean irradiance light varied between 557 (surface) and <1 umol photons $\mathrm{m}^{-2} \mathrm{~s}^{-1}(2.6 \mathrm{~m})$. Significant diurnal variation was evident in the penetration of light to 0.5 and $1.2 \mathrm{~m}$ within the ice and for temperatures recorded at 0.05 , 0.50 and $0.95 \mathrm{~m}$. Maximum irradiance and temperature at these depths was recorded at solar noon on days with limited cloud cover. In contrast, variation in the data collected by loggers embedded below $1.8 \mathrm{~m}$ was minimal. Salinity was derived from temperature measurements and is considered indicative only (Fig. 1).

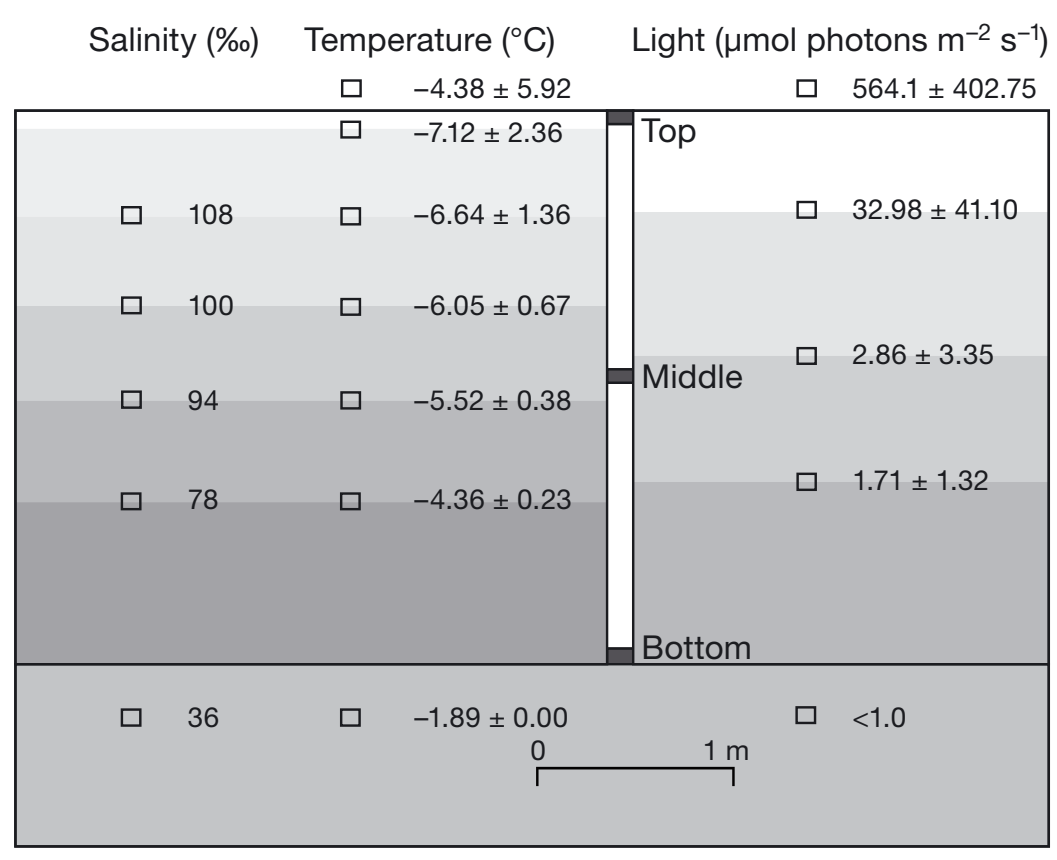

Fig. 1. Schematic representation and summary of data from light and temperature loggers (rectangles) deployed in annual fast-ice at Terra Nova Bay, Antarctica, between 15 November and 3 December 2006. Light and temperature data were collected every 5 and $20 \mathrm{~min}$, respectively. Data are means $\pm \mathrm{SD}$ recorded over $18 \mathrm{~d}$. Salinity was derived from the mean temperature. Under-ice irradiance was measured periodically using a $2 \pi$ sensor. Scale bar $=1 \mathrm{~m}$

\section{Distribution and abundance of sea-ice microbes}

Microbes were present in the top (0 to $0.1 \mathrm{~m}$ ), middle ( 1.25 to $1.35 \mathrm{~m}$ ) and bottom (2.5 to $2.6 \mathrm{~m}$ ) sections of all 12 extracted ice cores. At the start of the experiment $\left(t_{0}\right),>80 \%$ of the microbial cells and $>99 \%$ of the photosynthetic pigment chl a was concentrated in the bottom $100 \mathrm{~mm}$ of each core. This trend was still evident in the UC and DC treatments following $18 \mathrm{~d}$ of exposure to ambient conditions (Fig. 2).

Flipping had a significant effect on the average abundance of sea-ice microalgae, bacteria and the concentration of chl $a$, and these effects differed depending on the section of ice core (Table 1). The average abundance of microalgae originally at the bottom of the ice profile and flipped to the top (B-T) was not significantly different from the abundance of cells observed in the bottom section of the control cores (Table 1, Fig. 2b). In addition, the concentration of chl $a$ in the top of the flipped cores (B-T) was significantly higher than that in the top section of the control treatments (Table 1, Fig. 2a). For microalgae moved from the surface to the bottom of the ice (T-B), there was a significant increase in both the mean density of cells and the concentration of chl a (Table 1, Fig. 2a,b).

An increase in the average abundance of bacteria was observed in the bottom section of both control treatments compared with the $t_{0}$ treatment, but this increase was not observed in the bottom of the flipped (T-B) cores (Fig. 2c). For bottom-ice bacteria exposed to the surface of the ice profile (B-T; Fig. 2c), average cell numbers remained relatively high and did not differ significantly from the mean abundance of bacteria at the bottom of the control cores (Table 1). The average abundance of near-surface bacteria exposed to the ice-seawater interface (T-B, Fig. 2c) did not differ significantly from that measured at the top section of the control cores. There was no significant difference among treatments with respect to middle core sections for either bacteria or chl $a_{\text {, }}$ although a significant reduction of microalgae in the middle of the flipped cores relative to the controls was detected (Table 1).

There was a strong positive relationship between the abundance of microalgae and bacteria in the top, middle and bottom sections of the 9 control cores $(F=49.947$, p <0.001; Fig. 3a). Coupling between the algal and bacterial biomass was still evident at the end 

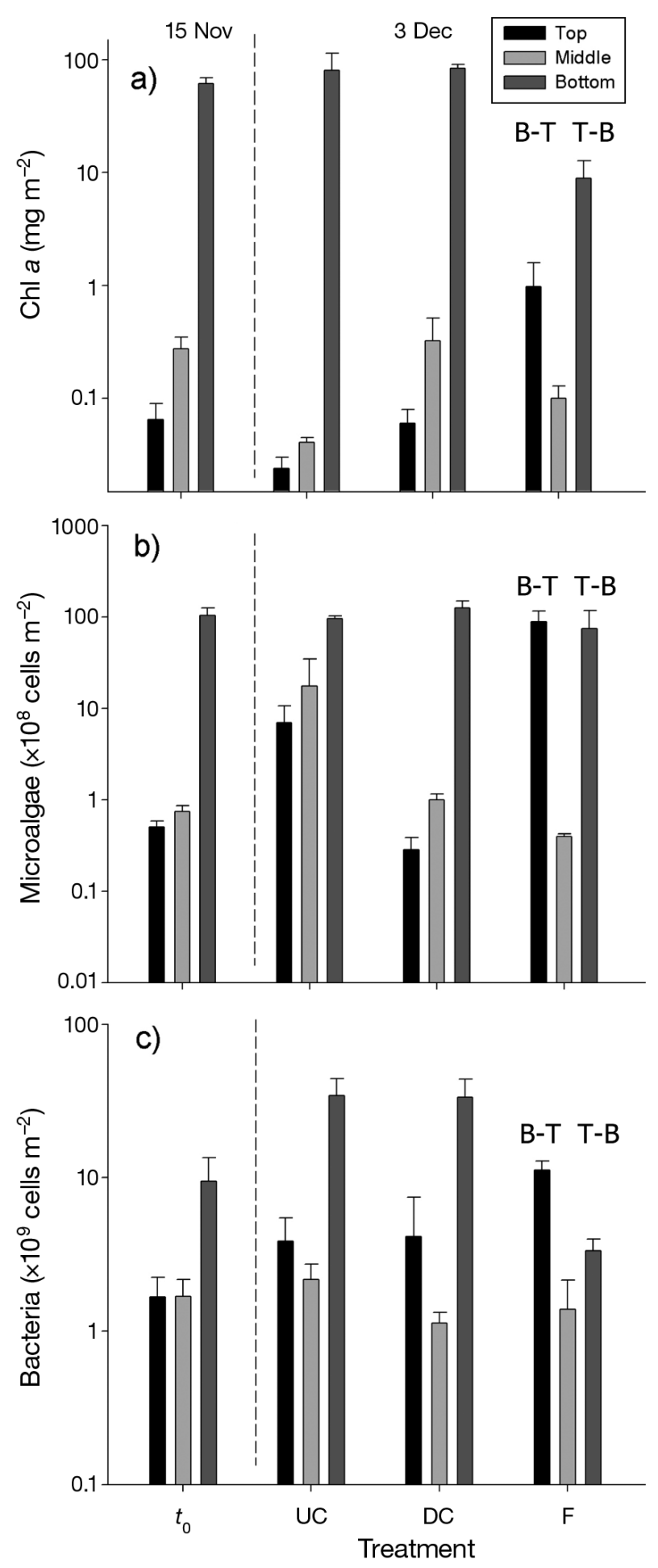

Fig. 2. (a) Concentration of chlorophyll a (chl a) and abundance of (b) microalgae and (c) bacteria in the top (0-0.1 m), middle $(1.25-1.35 \mathrm{~m})$ and bottom $(2.5-2.6 \mathrm{~m})$ sections of ice cores extracted on 2 occasions (15 November and 3 December 2006) from annual fast-ice in Terra Nova Bay, Antarctica $(\mathrm{n}=3)$. Treatments: time zero $\left(t_{0}\right)$, undisturbed control $(\mathrm{UC})$, disturbed control (DC) and flipped (F; B-T: bottom to top; T-B: top to bottom) of the experiment in the sections of the flipped cores, but the relationship was not as strong $(F=6.946, \mathrm{p}=$ 0.033; Fig. 3b).

\section{Community composition}

The microalgal fraction of the sea-ice community was dominated by diatoms from the genera Fragilariopsis, Navicula and Entomoneis (Table 2). PERMANOVA revealed a significant effect of flipping ice cores on the structure of the microalgal and protozoan assemblages within the ice that varied in size and/or direction with respect to core section (Table 1). The NMDS plot (Fig. 4a) shows an overall gradient in community structure for the microalgae and protozoa in the control treatments that reflected the known environmental gradients (top, middle and bottom) from the left to the lower right of the diagram. In contrast, for cores in the flipped treatment, microalgae that were initially at the top of the ice profile and flipped to the bottom (T-B) were found to be more similar to assemblages found at the top of the control cores (Fig. 4a, Table 1), indicating minimal change to the species composition. Similarly, assemblages flipped from the bottom to the top (B-T) were apparently more like the assemblages at the bottom of the control cores. There was no effect of flipping detected on the assemblages present in the middle of the ice cores (Table 1).

The number of bacterial phylotypes (DGGE bands) varied according to depth within the ice and, on average, 24, 16 and 17 discrete bands were detected in the bottom, middle and top sections of the control cores, respectively. For the UC and DC treatments, the NMDS plot shows bacterial assemblages from either the top or middle of the cores to the left of the diagram, whereas assemblages from the bottom occur at the lower right (Fig. 4b). Flipping had a variable effect on bacterial community structure (Table 1). The bacterial community originally at the bottom of the flipped cores (B-T) did not differ significantly from the bottom section of the control treatments (Table 1), and communities from the middle of the flipped cores remained similar to those found in the control cores. However, the results for bacterial communities originally at the top (T-B) of the flipped cores were less clear; these communities were marginally distinguishable $(0.05<\mathrm{p}<$ 0.10 ) from those found in either the top or the bottom sections of control treatments at the end of the experiment (Table 1, Fig. 4b).

Among the dominant phylotypes visualised with DGGE, 14 were successfully excised, re-run on a second DGGE gel to confirm migration location and subsequently sequenced. The 16S rRNA gene signatures identified from fast-ice at Terra Nova Bay showed vari- 
Table 1. Results of PERMANOVA on multivariate community data and individual univariate variables examining the interaction between a contrast of flipped (F) versus the 3 control treatments (time zero [ $\left.t_{0}\right]$, undisturbed [UC] and disturbed [DC]) and sections of the ice core (top, middle and bottom), followed by results testing specific contrasts, as indicated. T-B: communities flipped from top to bottom; B-T: communities flipped from bottom to top; C: control treatments. Values shown are $F$ (or pseudo- $F$ ) statistics for each test, with the associated $p$-values indicated. Non-significant: ${ }^{n}{ }^{,} p>0.10 ;{ }^{\sim}: 0.05<p<0.10 ;{ }^{*}: p<0.05 ;{ }^{* *}: p<0.001{ }^{* * *}: p<0.0001$. Note that for permutation tests, the $p$-values are not necessarily monotonic on the F-ratio values, even with similar degrees of freedom (df), as the null distribution of $F$ for each test is generated separately and necessarily depends on the specific data set from which it is generated

\begin{tabular}{|c|c|c|c|c|c|c|}
\hline & \multirow{2}{*}{$\begin{array}{l}\text { Interaction } \\
(\mathrm{df}=2,24)\end{array}$} & \multicolumn{5}{|c|}{ Contrasts $(\mathrm{df}=1,10)$} \\
\hline & & $\begin{array}{l}\text { T-B vs. } \\
\text { top C }\end{array}$ & $\begin{array}{l}\text { T-B vs. } \\
\text { bottom C }\end{array}$ & $\begin{array}{l}\text { B-T vs. } \\
\text { top C }\end{array}$ & $\begin{array}{l}\text { B-T vs. } \\
\text { bottom C }\end{array}$ & $\begin{array}{l}\text { F middle vs. } \\
\text { middle } C\end{array}$ \\
\hline \multicolumn{7}{|l|}{ Multivariate analyses } \\
\hline Microalgal community data & $2.20^{*}$ & $3.19^{\sim}$ & $3.88^{* *}$ & $4.44^{*}$ & $3.82^{* *}$ & $0.97^{\mathrm{ns}}$ \\
\hline Bacterial community data $^{a}$ & $3.75^{* *}$ & $4.82^{\sim}$ & $4.20^{\sim}$ & $6.54^{*}$ & $2.01^{\mathrm{ns}}$ & $4.28^{\sim}$ \\
\hline \multicolumn{7}{|l|}{ Univariate analyses } \\
\hline $\log$ cholorophyll a $\left(\mathrm{mg} \mathrm{m}^{-2}\right)$ & $18.57^{* * *}$ & $81.2^{* *}$ & $30.77^{* *}$ & $27.35^{* *}$ & $237.24^{* *}$ & $0.26^{\mathrm{ns}}$ \\
\hline log microalgae (cells $\mathrm{m}^{-2}$ ) & $21.00^{* * *}$ & $8.15^{*}$ & $3.74^{\mathrm{ns}}$ & $22.71^{* *}$ & $1.55^{\mathrm{ns}}$ & $12.10^{* *}$ \\
\hline log bacteria (cells $\mathrm{m}^{-2}$ ) & $11.49^{* * *}$ & $0.58^{\text {ns }}$ & $10.22^{* *}$ & $7.48^{*}$ & $1.63^{\mathrm{ns}}$ & $0.40^{\mathrm{ns}}$ \\
\hline
\end{tabular}
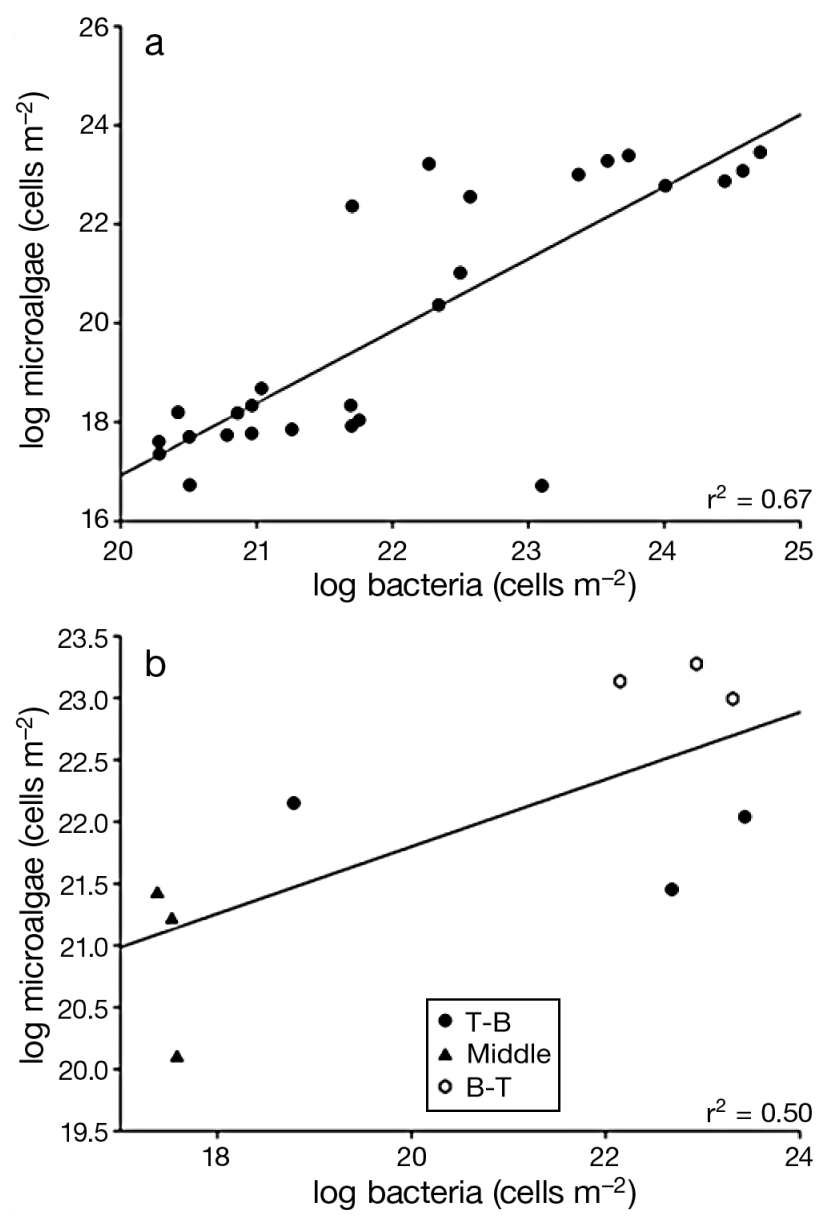

Fig. 3. Correlation between the log abundance (cells $\mathrm{m}^{-2}$ ) of bacteria and microalgae in the top $(0-0.1 \mathrm{~m})$, middle $(1.25-1.35 \mathrm{~m})$ and bottom $(2.5-2.6 \mathrm{~m})$ sections of ice cores extracted from annual fast-ice in Terra Nova Bay. (a) Combined control treatments (time zero, undisturbed and disturbed); (b) flipped cores (T-B: top to bottom; B-T: bottom to top) able identity (83.3 to $100 \%$ ) to sequences of polar origin in the NCBI GenBank database. Eleven bands were affiliated with either the Alpha or Gamma subdivision of the Proteobacteria, whereas one band was affiliated with the Firmicutes (Table 3).

\section{DISCUSSION}

The relationship between community composition and ecosystem function has generally been ignored in the field of microbial ecology (Reed \& Martiny 2007); however, it is becoming increasingly urgent to anticipate the consequences of the loss of annual ice predicted for the Antarctic coastal ecosystem (17 to 31\%) within the next century (Rind et al. 1997, Meehl et al. 2000, Arrigo \& Thomas 2004). Although reciprocal transplant experiments are considered useful in simultaneously examining how community composition and environmental variables influence ecosystem function (Reed \& Martiny 2007, Allison \& Martiny 2008), until now this methodology had not been applied to Antarctic sea-ice.

The ice thickness at Terra Nova Bay in November 2006 was $2.6 \mathrm{~m}$, which is significantly thicker than most fast-ice in coastal regions of Antarctica. Considerable care was thus taken in reinserting cores of this length (DC and flipped treatments) back into the ice. However, within $24 \mathrm{~h}$ it was evident that each core had reintegrated into the surrounding matrix, and this was confirmed when the cores were extracted at the conclusion of the experiment. The collection of physical data from within the ice is uncommon in ecological studies, primarily because of the logistical constraints of embedding and subsequently retrieving probes 
Table 2. Summary of microalgae and protozoa identified in this study. Values show the contribution (\%) to total cell counts for core sections of interest. Haptophytes were not included in this analysis. (nd: not determined). Time zero $\left(t_{0}\right)$, disturbed control (DC) and flipped (F) refer to experimental treatments; bottom

(B), middle (M) and top (T) refer to core sections. Blanks: no cells found

\begin{tabular}{|c|c|c|c|c|c|c|c|c|c|}
\hline \multirow[t]{2}{*}{ Taxon } & \multirow[b]{2}{*}{$t_{0} \mathrm{~B}$} & \multirow[b]{2}{*}{ DCB } & \multicolumn{5}{|c|}{ - Treatment and core section } & \multirow[b]{2}{*}{ DCT } & \multirow[b]{2}{*}{ FB } \\
\hline & & & FT & $t_{0} \mathrm{M}$ & DCM & $\mathrm{FM}$ & $t_{0} \mathrm{~T}$ & & \\
\hline \multicolumn{10}{|l|}{ Autotrophs $>20 \mu \mathrm{m}$} \\
\hline Berkeleya sp. & 13.4 & 7.2 & 12.7 & 1.3 & 2.1 & & & & 3.6 \\
\hline Chaetoceros sp. & & & & $<1.0$ & & & & & \\
\hline Chlorophyte sp. 1 & & & & & 8.7 & & & & \\
\hline Cylindrotheca sp. & & & & $<1.0$ & & & 7.2 & & \\
\hline Entomoneis sp. 1 & 23.9 & 20.7 & 21.6 & 16.3 & 17 & 10.9 & 4.3 & 18.8 & 11.3 \\
\hline Entomoneis sp. 2 & & $<1.0$ & $<1.0$ & & & & & & $<1.0$ \\
\hline Eucampia antarctica & & & & & & & & & $<1.0$ \\
\hline Fragilariopsis curta & 11.7 & 20 & 10.4 & 16.1 & 20.8 & 31.9 & 27 & 15.7 & 22.2 \\
\hline Fragilariopsis cylindrus & 5.4 & 5.8 & 5.1 & 11.3 & 4.4 & 8.8 & 26.6 & 14.2 & 8.2 \\
\hline Fragilariopsis rhombica & $<1.0$ & 1.1 & & & & & & & \\
\hline Fragilariopsis sp. 1 & 1.6 & 1.9 & 3.1 & $<1.0$ & 5.6 & 5.4 & & 3.3 & 10.7 \\
\hline Fragilariopsis sp. 2 & 0.1 & 0.2 & & & & & & & \\
\hline Fragilariopsis sublinearis & & $<1.0$ & $<1.0$ & & & 1.4 & & & $<1.0$ \\
\hline Haptophyte & nd & nd & nd & nd & nd & nd & nd & nd & nd \\
\hline Navicula sp. 1 & 30.7 & 30.5 & 43 & 24.6 & 26 & 24 & 11.5 & 21.8 & 36.8 \\
\hline Nitzschia lecointei & 1.2 & 1.6 & 1.1 & 12.4 & 2.3 & & 4.3 & 2.2 & $<1.0$ \\
\hline Nitzschia sp. 1 & $<1.0$ & 1.2 & $<1.0$ & & & & 1.8 & 2.7 & $<1.0$ \\
\hline Nitzschia sp. 2 & $<1.0$ & & $<1.0$ & & $<1.0$ & & & & \\
\hline Nitzschia stellata & 7.1 & 3.4 & & 5.1 & 1 & & & & \\
\hline Pinnularia sp. & $<1.0$ & $<1.0$ & $<1.0$ & 1.2 & $<1.0$ & 1.1 & 3.2 & & \\
\hline Pleurosigma sp. & $<1.0$ & $<1.0$ & $<1.0$ & & & & & & \\
\hline Pseudo-nitzschia sp. & 1.5 & 1.5 & $<1.0$ & 2.2 & 1.9 & & 6.5 & 4.6 & $<1.0$ \\
\hline Centric diatom & 1.1 & 1.1 & 1.2 & 6.9 & 4.5 & 5.2 & 7.6 & 10.2 & 3.5 \\
\hline \multicolumn{10}{|l|}{ Heterotrophs $>20 \mu \mathrm{m}$} \\
\hline Ciliate sp. 1 & & $<1.0$ & & & $<1.0$ & & & & \\
\hline Dinoflagellate cyst & & & & & & 1.2 & & & $<1.0$ \\
\hline Dinoflagellate sp. 1 & $<1.0$ & $<1.0$ & & & & & & & $<1.0$ \\
\hline Large flagellate or cyst & 1 & 1.7 & $<1.0$ & & 4 & 10 & & 6.5 & 1.7 \\
\hline Protoperidinium sp. & & & $<1.0$ & & & & & & $<1.0$ \\
\hline Silicoflagellate sp. 1 & & & $<1.0$ & $<1.0$ & & & & & \\
\hline
\end{tabular}

(Lazzara et al. 2007). As a result, PAR is often derived using radiative transfer models (Maykut \& Grenfell 1975), but we opted to collect direct measurements for greater accuracy. For bottom-ice microbes that were exposed to the surface region of the ice, in situ irradiance increased dramatically from $<1$ to $540 \mu \mathrm{mol}$ photons $\mathrm{m}^{-2} \mathrm{~s}^{-1}$ and this was accompanied by an average drop in temperature of $4^{\circ} \mathrm{C}$ and a potential 3 -fold increase in salinity. In contrast, microbes acclimated to the surface and moved to the bottom of the ice were subjected to warmer, less saline conditions that are typical of the water column $\left(-1.8^{\circ} \mathrm{C}, 36 \%\right)$, but high light attenuation due to the overlying ice.

In general, the control treatments were useful in documenting the distribution and abundance of microbial assemblages, illustrating change in relative abundances over $18 \mathrm{~d}$, and confirming that the community was not significantly influenced by shearing of the ice or temporary core removal (Fig. 2, Tables 1 \& 2). The bottom or congelation layer of annual fast-ice is normally characterised by a rapid increase in microalgal biomass during the austral spring (Ryan et al. 2006), but there was no significant change in the average abundance of microalgae and protozoa or concentration of $\mathrm{chl} \mathrm{a}$

\section{Macroalgal communities}

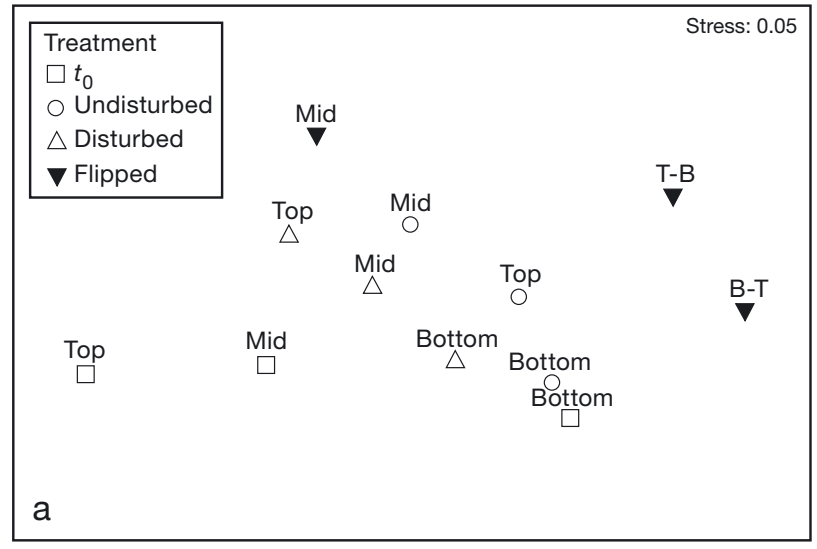

Bacterial phylotypes

\begin{tabular}{|c|c|c|c|}
\hline $\begin{array}{l}\text { Treatment } \\
\bigcirc \text { Undisturbed } \\
\triangle \text { Disturbed } \\
\nabla \text { Flipped }\end{array}$ & Top & $\stackrel{\mathrm{T}-\mathrm{B}}{\nabla}$ & $\begin{array}{l}\text { Stress: } 0.06 \\
\text { B-T } \\
\nabla\end{array}$ \\
\hline $\begin{array}{l}\text { Mid } \\
\text { Top } \\
\text { O }\end{array}$ & $\underset{\triangle}{\operatorname{Mid}}$ & $\operatorname{Mid}$ & $\underset{\triangle}{\text { Bottom }}$ \\
\hline b & & & $\begin{array}{c}\text { Bottom } \\
\bigcirc\end{array}$ \\
\hline
\end{tabular}

Fig. 4. (a) Non-metric multidimensional scaling (NMDS) plot of centroids $(n=3)$ for the 12 combinations of Treatment $\times$ Section, based on the Bray-Curtis dissimilarity matrix among sample units calculated from square-root-transformed standardised abundances of algal community data (30 variables). (b) NMDS plot of centroids $(n=3)$ for the 9 combinations of Treatment $\times$ Section (time zero $\left[t_{0}\right]$ cores omitted), based on the Dice (Sørensen) similarity matrix among sample units calculated from denaturing gradient gel electrophoresis (DGGE) band patterns of bacterial phylotypes. Mid: middle; T-B: cores flipped from top to bottom; 
Table 3. Phylogenetic affiliation of sequences obtained from denaturing gradient gel electrophoresis (DGGE) bands with closest matches from BLAST search of the GenBank database. Sequence similarity was calculated from $160 \mathrm{bp}$

\begin{tabular}{|c|c|c|c|c|c|}
\hline $\begin{array}{l}\text { Band } \\
\text { (accession no.) }\end{array}$ & $\begin{array}{l}\text { Closest match environmental } \\
\text { or culture }\end{array}$ & $\begin{array}{c}\text { Sequence } \\
\text { similarity }(\%)\end{array}$ & Taxonomic group & Source & Accession no. \\
\hline \multirow[t]{3}{*}{$\begin{array}{l}\text { B-1 } \\
\text { (HQ609845) }\end{array}$} & Pseudoalteromonas sp. BSw20083 & 100 & $\begin{array}{l}\text { Gammaproteobacteria/ } \\
\text { Pseudoalteromonadaceae }\end{array}$ & $\begin{array}{l}\text { Arctic } \\
\text { seawater }\end{array}$ & EU365608 \\
\hline & $\begin{array}{l}\text { Pseudoalteromonas haloplanktis } \\
\text { clone SE61 }\end{array}$ & 100 & $\begin{array}{l}\text { Gammaproteobacteria/ } \\
\text { Pseudoalteromonadaceae }\end{array}$ & $\begin{array}{l}\text { Arctic } \\
\text { seawater }\end{array}$ & AY771767 \\
\hline & Polar sea bacterium R7076 & 100 & Bacteria & Polar seawater & AJ295713 \\
\hline $\begin{array}{l}\text { B-2 } \\
\text { (HQ609846) }\end{array}$ & Pseudoalteromonas sp. BSi20674 & 93.2 & $\begin{array}{l}\text { Gammaproteobacteria/ } \\
\text { Pseudoalteromonadaceae }\end{array}$ & Arctic sea-ice & DQ517881 \\
\hline \multirow[t]{2}{*}{$\begin{array}{l}\text { B-3 } \\
\text { (HQ609847) }\end{array}$} & Pseudoalteromonas sp. Zao-C & 97 & $\begin{array}{l}\text { Gammaproteobacterial } \\
\text { Pseudoalteromonadaceae }\end{array}$ & Polar & FJ362496 \\
\hline & Pseudoalteromonas sp. L203 & 97 & $\begin{array}{l}\text { Gammaproteobacterial } \\
\text { Pseudoalteromonadaceae }\end{array}$ & Antarctica & EU828455 \\
\hline $\begin{array}{l}\text { B-4 } \\
\text { (HQ609848) }\end{array}$ & Loktanella sp. ZS2-13 & 100 & $\begin{array}{l}\text { Alphaproteobacteria/ } \\
\text { Rhodobacteraceae }\end{array}$ & $\begin{array}{l}\text { Antarctic } \\
\text { marine sediments }\end{array}$ & FJ195992 \\
\hline $\begin{array}{l}\text { B-5 } \\
\text { (HQ609849) }\end{array}$ & Bacillus sp. & 100 & Firmicutes, Bacillaceae & Marine & Y14144 \\
\hline $\begin{array}{l}\text { B-6 } \\
\text { (HQ609850) }\end{array}$ & Colwellia sp. NJ341 & 100 & $\begin{array}{l}\text { Gammaproteobacteria/ } \\
\text { Colwelliaceae }\end{array}$ & $\begin{array}{l}\text { Antarctic } \\
\text { psychrophile }\end{array}$ & AY781156 \\
\hline $\begin{array}{l}\text { B-7 } \\
\text { (HQ609851) }\end{array}$ & Marinomonas sp. BSi20448 & 100 & $\begin{array}{l}\text { Gammaproteobacteria/ } \\
\text { Oceanospirillales }\end{array}$ & Arctic sea-ice & EF673291 \\
\hline $\begin{array}{l}\text { B-8 } \\
\text { (HQ609852) }\end{array}$ & Loktanella sp. ZS2-13 & 96.2 & $\begin{array}{l}\text { Alphaproteobacteria/ } \\
\text { Rhodobacteraceae }\end{array}$ & $\begin{array}{l}\text { Antarctic } \\
\text { marine sediments }\end{array}$ & FJ195992 \\
\hline \multirow[t]{2}{*}{$\begin{array}{l}\text { B-9 } \\
\text { (HQ609853) }\end{array}$} & Roseobacter sp. ANT9274 & 100 & $\begin{array}{l}\text { Alphaproteobacterial } \\
\text { Rhodobacteraceae }\end{array}$ & Sea-ice & AY167261 \\
\hline & Roseobacter sp. ANT9234 & 100 & $\begin{array}{l}\text { Alphaproteobacteria/ } \\
\text { Rhodobacteraceae }\end{array}$ & Sea-ice & AY167257 \\
\hline $\begin{array}{l}\text { B-10 } \\
\text { (HQ609854) }\end{array}$ & Colwellia sp. BSw20087 & 100 & $\begin{array}{l}\text { Gammaproteobacteria/ } \\
\text { Colwelliaceae }\end{array}$ & Arctic seawater & EU433333 \\
\hline $\begin{array}{l}\text { B-11 } \\
\text { (HQ609855) }\end{array}$ & Loktanella sp. ZS2-13 & 98.4 & $\begin{array}{l}\text { Alphaproteobacteria/ } \\
\text { Rhodobacteraceae }\end{array}$ & $\begin{array}{l}\text { Antarctic } \\
\text { marine sediments }\end{array}$ & FJ195992 \\
\hline $\begin{array}{l}\text { B-12 } \\
\text { (HQ609856) }\end{array}$ & Pseudoalteromonas sp. BSi20674 & 95.6 & $\begin{array}{l}\text { Gammaproteobacterial } \\
\text { Pseudoalteromonadaceae }\end{array}$ & Arctic sea-ice & DQ517881 \\
\hline
\end{tabular}

after $18 \mathrm{~d}$ in either the bottom, middle or top sections of the control treatments (Fig. 2).

Although the physicochemical characteristics of the ice in the flipped cores were not quantified at the end of the present study, changes to the internal structure of the ice will have influenced microbial processes. The formation of brine pockets and channels as secondary structural features within the ice is largely determined by gravity and the vertical temperature and salinity gradient (Garrison 1991, Arrigo \& Sullivan 1992). Changes to the concentration of brine and distribution of DOM within the flipped cores and subsequent variation in the size and density of brine channels and pores must be considered with respect to in situ microbial growth and the interaction with grazers. In addition, the exposure of highly shadeadapted bottom-ice microalgae to the surface of the ice in the flipped treatment is likely to have killed a number of the algal cells present, as evidenced by significant bleaching of chl $a$ and change in community composition (Figs. 1 \& 4a, Table 2). Optimal growth by ice-associated microalgae occurs at irradiances of $<200 \mu \mathrm{mol}$ photons $\mathrm{m}^{-2} \mathrm{~s}^{-1}$ and exposure to high irradiances has been shown to cause photoinhibition or reduced photosynthetic efficiency (Ralph et al. 2007, Ryan et al. 2009). However, Mangoni et al. (2009) have recently documented the extraction of ice cores from Terra Nova Bay and subsequent survival of sea-ice microalgae that were exposed to $\sim 42 \mu \mathrm{mol}$ photons $\mathrm{m}^{-2} \mathrm{~s}^{-1}$ for $12 \mathrm{~d}$, and Griffith et al. (2009) have described a photoprotective response whereby excess thermal energy is dissipated via the diadinoxanthin (DD) cycle. Although zero net growth was recorded over a period of $18 \mathrm{~d}$ in the present study, chl a was still detectable at the top of the flipped cores, which suggests that a proportion of the cells survived the $500 \%$ increase in irradiance. The rapid growth of microalgae formerly exposed to high irradiances (i.e. T-B) observed here may indicate that the limited growth generally observed in surface sections of the ice is due not only to the relatively high irradiances experienced there, but also to low temperature and a 
reduction in nutrient availability. Given that the B-T assemblage was originally in close proximity with the nutrient-rich water column, it is likely that limited nitrate and, in particular, iron (potentially enhanced by nutrients leaching down through the ice) may have restricted the synthesis of proteins and pigments that are required for acclimation to high light (Mock \& Kroon 2002). A reduction in temperature will also have exposed this assemblage to increased salinity, and this has recently been shown to exacerbate the photosynthetic stress response in microalgae incubated under high light (Ralph et al. 2007).

In contrast, the average abundance of cells originally at the top of the ice profile increased significantly when exposed to the ice-seawater interface (Fig. 2). The main limitation to primary production in bottom-ice assemblages is usually light attenuation from the overlying ice. In 1.5 to $1.8 \mathrm{~m}$ fast-ice with 5 to $10 \mathrm{~cm}$ of snow cover, the midday in situ irradiance is only 1 to $10 \mu \mathrm{mol}$ photons $\mathrm{m}^{-2} \mathrm{~s}^{-1}$ (McMinn et al. 1999b). However, microalgae have photosynthetic mechanisms that saturate at low irradiances, and although photoacclimation requires change in both the concentration and composition of intracellular photosynthetic pigments, growth can be maintained at $0.3 \mu \mathrm{mol}$ photons $\mathrm{m}^{-2} \mathrm{~s}^{-1}$ (Palmisano \& Sullivan 1983, Thomas \& Dieckmann 2002).

Although the community composition in the T-B sections of the flipped cores differed from the bottom sections of the control treatments (Fig. 4a, Tables 1 \& 2) (Berkeleya sp. and several other species were newly acquired), the general increase in the abundance of microalgae appears to have originated from pre-existing species within the ice rather than a suite of new cells scavenged from the water column. The lack of growth during $18 \mathrm{~d}$ in the bottom section of the control treatments might be explained by high light attenuation from the overlying ice subsequently leading to self-shading by pre-existing phototrophic cells. This limit to algal growth was essentially relaxed in the bottom of the flipped cores, enabling a period of rapid colonisation by cells from the surrounding matrix and/or growth of cells that were initially at the surface of the ice profile (Fig. 2).

Despite the application of both cultivation- and molecular-based studies, an understanding of the functional capabilities of bacteria in Antarctic sea-ice still remains fragmentary (Murray \& Grzymski 2007). Following the initial freeze, psychrophilic species are known to dominate bacterial populations. Heterotrophic cells from both the bottom-ice and high-brine regions exhibit relatively high metabolic activity (Kottmeier et al. 1987, Martin et al. 2008), but the taxonomic diversity of sea-ice bacteria, either vertically within the ice or across geographical regions, remains poorly understood. In contrast to the microalgal frac- tion of the community, the number of bacterial cells increased during the course of the experiment in both the top and bottom sections of the control treatments (Fig. 2c). Whether sea-ice bacteria exhibit speciesspecific environmental tolerances, and how this relates to the availability of growth substrates, is not currently known, but both the number of cells and the number of DGGE-generated phylotypes were significantly greater in the bottom section of the control cores. Despite the degradation of light-shocked microalgae and likely increase in the concentration of DOM at the top of the flipped cores, we did not observe an increase in the abundance of bacterial cells. This suggests that a $5^{\circ} \mathrm{C}$ reduction in ambient temperature had a significant effect on the ability of bacteria to utilise this substrate. Although the effects of low temperature, high salinity and high light are essentially confounded, temperature-limited growth offers the most likely explanation as bottom-ice bacteria have been shown to exhibit a high tolerance to increased saline concentrations (Kottmeier \& Sullivan 1988, Martin et al. 2009) and the presence of light-sensitive bacteria within the ice matrix has yet to be confirmed.

Limited experimental work with sea-ice microbial communities with respect to DOM has highlighted the rapid response of bacteria to algal-derived exudates (Giesenhagen et al. 1999, Martin et al. 2009), but it is not clear whether this reflects in situ microbial loop dynamics. The positive correlation observed in the present study between microalgae and bacteria present in the top, middle and bottom core sections implies an active microbial loop at the time of sampling (Fig. 3), but minimal growth by microalgae between 15 November and 3 December signals a plateau in the autotrophic growth which typically occurs in mid-late November in Terra Nova Bay (Lazzara et al. 2007). The continued increase of bacteria in the control treatments is most likely due to a lag in the response time of bacteria to the photosynthate made available during the development of the microalgal biomass (Archer et al. 1996, Garrison et al. 2005). Of equal importance to the microbial loop is the consumption of bacteria by protozoan grazers. Although a number of flagellates and ciliates were identified within the ice, a significant increase in the abundance of these grazers was not observed during the course of the experiment, which may again be indicative of a lag in response time.

The delayed response of bacteria to the presumed increased availability of microalgal photosynthate at the bottom of the flipped cores has important implications for the interpretation of previous in vitro experiments. We have recently cultured sea-ice microbes for a period of $9 \mathrm{~d}$ and found that both the growth rate and degree of intracellular activity in surface bacteria was significantly lower than bacteria derived from the 
bottom-ice layer (authors' unpubl. obs.). A possible interpretation of this finding is that only slow-growing psychrophilic species are capable of acclimating to both reduced temperature and high salinity. The present study supports this supposition, as the bacteria originally near the surface of the ice did not respond within $18 \mathrm{~d}$ to either the influx of nutrients from the water column or the increase of algal-derived DOM. Although a significant change in the abundance of bacteria in the flipped cores was not detected, we do provide some evidence for a shift in DGGE phylotypes detected in the T-B cores (Fig. 4b). The change in community composition may be the prelude to a significant growth response by pre-existing cells or it may indicate colonisation by bacteria present in the water column or surrounding ice. Within the context of an $18 \mathrm{~d}$ experiment, the lack of either dramatic growth or change in bacterial community composition in the flipped cores implies a 'malfunction' of the microbial loop; although there was a likely increase in substrates available for bacterial metabolism, the number of cells within the ice remained constant. An alternative explanation is that bacteria in the flipped cores may have initially increased, but were grazed prior to core extraction at the end of the experiment. Given the low number of flagellates and ciliates found within the ice, this interpretation appears unlikely and the data instead support the findings of Grossmann \& Gleitz (1993), who examined the microbial response to experimental sea-ice formation and determined that the period of time required before algal exudates influenced bacterial production was in excess of $2 \mathrm{wk}$.

To our knowledge, there is only one study to date where various primer combinations have been applied to the same set of environmental samples prior to DGGE analysis (Sánchez et al. 2007). These authors suggested that the primers 357F and 907RM may be suitable for bacteria in most marine systems, but this combination could not be optimised for our samples. We therefore accepted a reduced amplicon length ( 160 bp) with which to obtain phylogenetic information by using the primers $357 \mathrm{~F}$ and $518 \mathrm{R}$, which was the combination secondarily favoured by Sánchez et al. (2007). Importantly, a number of bands at different locations on different gels had similar sequences (Table 3). This may reflect the limited nucleotide resolution, but we also acknowledge the various biases that are inherent to DGGE analysis, including DNA extraction efficiency, rRNA gene copy number and PCR primer annealing efficiency (see Reysenbach et al. 1992, Farrelly et al. 1995 for reviews). However, the excised DGGE bands showed acceptable (>90\%) similarity to Alphaproteobacteria, Gammaproteobacteria and Firmicutes sequences from polar regions. While Archaea are not thought to be numerically abundant within Antarctic sea-ice (Brown \& Bowman 2001), screening for the presence of this taxonomic group would have made a useful addition to this study.

Although microbial assemblages within the sea-ice ecosystem are functionally similar, they do not appear to be functionally redundant. This is largely due to the seasonal development of the microbial community, whereby assemblages become finely attuned to discrete physicochemical conditions within the ice. In general, the degree of resilience exhibited by sea-ice bacteria may be higher than that of microalgae; however, a lag in the growth response of bacteria to algalderived DOM in the cores that were flipped potentially caused a 'malfunction' of the microbial loop. The ability of microalgae to regulate the composition and concentration of photosynthetic pigments is a particularly advantageous response to variation in ambient irradiance; however, rapid disturbance causes significant physiological stress. The reciprocal transplant methodology confers a number of advantages over in vitro methods that rely on melted ice cores or extracted brine, yielding novel insights into microbial dynamics in the Antarctic sea-ice ecosystem.

Acknowledgements. We acknowledge the logistical support of Antarctica New Zealand and, in particular, S. Gordon, Project Manager of the Latitudinal Gradient Project. A.M. was supported by a Victoria University of Wellington Postgraduate Scholarship for PhD Study and also thanks the Trans Antarctic Association for support in funding this research, K. M. Hare for graphic design and M. Kennedy for advice on phylogenetics. K.G.R. acknowledges the support of the Foundation of Research, Science \& Technology (contract no. VICX0706).

\section{LITERATURE CITED}

Ackley SF, Sullivan CW (1994) Physical controls on the development and characteristics of Antarctic sea-ice biological communities: a review and synthesis. Deep-Sea Res I 41: 1583-1604

Allison SD, Martiny JBH (2008) Resistance, resilience, and redundancy in microbial communities. Proc Natl Acad Sci USA 105:11512-11519

Anderson MJ (2001) A new method for non-parametric multivariate analysis of variance. Austral Ecol 26:32-46

Anderson MJ, Gorley RN, Clarke KR (2008) PERMANOVA+ for PRIMER. Guide to software and statistical methods. PRIMER-E Ltd, Plymouth

Archer SD, Leakey RJG, Burkill PH, Sleigh MA, Appleby CJ (1996) Microbial ecology of sea-ice at a coastal Antarctic site: community composition, biomass and temporal change. Mar Ecol Prog Ser 135:179-195

Arrigo KR, Sullivan CW (1992) The influence of salinity and temperature covariation on the photophysiological characteristics of Antarctic sea-ice microalgae. J Phycol 28: 746-756

> Arrigo KR, Thomas DN (2004) Large scale importance of seaice biology in the Southern Ocean. Antarct Sci 16:471-486

> Arrigo KR, Lizotte MP, Dixon P, Dieckmann G (1997) Primary production in Antarctic sea-ice. Science 276:394-397 
Arrigo KR, Worthen D, Schnell A, Lizotte M (1998) Primary production in Southern Ocean waters. J Geophys Res 103: 15587-15600 doi:10/1029/98JC00930

Azam F, Malfatti F (2007) Microbial structuring of marine ecosystems. Nat Rev Microbiol 5:782-791

> Azam F, Smith DC, Hollibaugh JT (1991) The role of the microbial loop in Antarctic pelagic ecosystems. Polar Res 10:239-243

Bray JR, Curtis JT (1957) An ordination of the upland forest communities of southern Wisconsin. Ecol Monogr 27: 325-349

Brown MV, Bowman JP (2001) A molecular phylogenetic survey of sea-ice microbial communities (SIMCO). FEMS Microbiol Ecol 35:267-275

Clarke KR, Gorley RN (2006) PRIMER v6: user manual/ tutorial. PRIMER-E Ltd, Plymouth

Clarke KR, Green RH (1988) Statistical design and analysis for a 'biological effects' study. Mar Ecol Prog Ser 46:213-226

Clarke KR, Warwick RM (2001) Change in marine communities, 2nd edn. PRIMER-E Ltd, Plymouth

Cox GFN, Weeks WF (1986) Changes in the salinity and porosity of sea-ice samples during shipping and storage. J Glaciol 32:371-375

Daly KL (1990) Overwintering development, growth, and feeding of larval Euphausia superba in the Antarctic marginal ice zone. Limnol Oceanogr 35:1564-1576

Delille D, Fiala M, Rosiers C (1995) Seasonal changes in phytoplankton and bacterioplankton distribution at the ice-water interface in the Antarctic neritic area. Mar Ecol Prog Ser 123:225-233

> Delille D, Fiala M, Kuparinen J, Kuosa H, Plessis C (2002) Seasonal changes in microbial biomass in the first-year ice of the Terre Adélie area (Antarctica). Aquat Microb Ecol 28:257-265

Deming JW (2002) Psychrophiles and polar regions. Curr Opin Microbiol 5:301-309

Evans CA, O'Reilly JE, Thomas JP (1987) A handbook for the measurement of chlorophyll $a$ and primary production. A\&M University, College Station, TX

Farrelly V, Rainey FA, Stackebrandt E (1995) Effect of genome size and rRNA gene copy number on PCR amplification of 16S rRNA genes from a mixture of bacterial species. Appl Environ Microbiol 61:2789-2801

Fiala M, Kuosa H, Kopczyńska EE, Oriol L, Delille D (2006) Spatial and seasonal heterogeneity of sea-ice microbial communities in the first-year ice of Terre Adélie area (Antarctica). Aquat Microb Ecol 43:95-106

> Fritsen CH, Coale SL, Neenan DR, Gibson AH, Garrison DL (2001) Biomass, production and microhabitat characteristics near the freeboard of ice floes in the Ross Sea, Antarctica, during the austral summer. Ann Glaciol 33:280-286

Garrison DL (1991) Antarctic sea-ice biota. Am Zool 31:17-33

> Garrison DL, Gibson A, Coale SL, Gowing MM, Okolodkov YB, Fritsen HF, Jeffries MO (2005) Sea-ice microbial communities in the Ross Sea: autumn and summer biota. Mar Ecol Prog Ser 300:39-52

> Giesenhagen HC, Detmer AE, de Wall J, Weber A, Gradinger RR, Jochem FJ (1999) How are Antarctic planktonic microbial food webs and algal blooms affected by melting of seaice? Microcosm simulations. Aquat Microb Ecol 20:183-201

Gowing MM, Garrison DL, Gibson AH, Krupp JM, Jefferies MO, Fritsen CH (2004) Bacterial and viral abundances in Ross Sea summer pack ice communities. Mar Ecol Prog Ser 279:3-12

Griffith GP, Vennell R, Lamare MD (2009) Diadinoxanthin cycle of the bottom ice algae community during spring in McMurdo Sound, Antarctica. Polar Biol 32:623-636
Grossmann S, Gleitz M (1993) Microbial responses to experimental sea-ice formation: implications for the establishment of Antarctic sea-ice communities. J Exp Mar Biol Ecol 173:273-289

Günther S, Gleitz M, Dieckmann GS (1999) Biogeochemistry of Antarctic sea-ice: a case study on platelet ice layers at Drescher Inlet, Weddell Sea. Mar Ecol Prog Ser 177:1-13

> Helmke E, Weyland H (1995) Bacteria in sea ice and underlying water of the eastern Weddell Sea in midwinter. Mar Ecol Prog Ser 117:141-163

Horner RA (1985) Ecology of sea-ice microalgae. In: Horner RA (ed) Sea-ice biota. CRC Press, Boca Raton, FL, p 83-103

Junge K, Krembs C, Deming J, Stierle A, Eicken H (2001) A microscopic approach to investigate bacteria under in situ conditions in sea-ice samples. Ann Glaciol 33:304-310

> Kottmeier ST, Sullivan CW (1988) Sea ice microbial communities IX. Effects of temperature and salinity on metabolism and growth of autotrophs and heterotrophs. Polar Biol 8: 293-304

> Kottmeier ST, Sullivan CW (1990) Bacterial biomass and production in pack ice of Antarctic marginal ice edge zones. Deep-Sea Res Part A 37:1311-1330

> Kottmeier ST, Grossi SM, Sullivan CW (1987) Sea-ice microbial communities. VIII. Bacterial production in annual seaice of McMurdo Sound, Antarctica. Mar Ecol Prog Ser 35: 175-186

Krembs C, Eicken H, Junge K, Demming J (2002) High concentrations of exopolymeric substances in Arctic winter ice: implications for the polar ocean carbon cycle and cryoprotection of diatoms. Deep-Sea Res 49:2163-2181

Lazzara L, Nardello I, Ermanni C, Mangoni O, Saggiomo V (2007) Light environment and season dynamics of microalgae in the annual sea-ice at Terra Nova Bay, Ross Sea, Antarctica. Antarct Sci 19:83-92

Legendre L, Ackley SF, Dieckmann GS, Gulliksen B and others (1992) Ecology of sea-ice biota. 2. Global significance. Polar Biol 12:429-444

Lizotte M (2001) The contributions of sea-ice algae to Antarctic marine primary production. Am Zool 41:57-73

Mangoni O, Carrade GC, Modigh M, Catalano G, Saggiomo V (2009) Photoacclimation in Antarctic bottom ice algae: an experimental approach. Polar Biol 32:325-335

Manly BFJ (2006) Randomisation, bootstrap and Monte Carlo methods in biology, 3rd edn. Chapman \& Hall, London

> Martin A, Hall JA, O'Toole R, Davy SK, Ryan KG (2008) High single-cell metabolic activity in Antarctic sea-ice bacteria. Aquat Microb Ecol 52:25-31

Martin A, Hall JA, Ryan KG (2009) Low salinity and highlevel UV-B radiation reduce single-cell activity in Antarctic sea-ice bacteria. Appl Environ Microbiol 75:7570-7573

Maykut GA, Grenfell TC (1975) The spectral distribution of light beneath first-year sea-ice in the Arctic Ocean. Limnol Oceanogr 20:554-563

> McArdle BH, Anderson MJ (2001) Fitting multivariate models to community data: a comment on distance-based redundancy analysis. Ecology 82:290-297

McGrath Grossi SM, Kottmeier ST, Sullivan CW (1984) Seaice microbial communities III. Seasonal abundance of microalgae associated bacteria in McMurdo Sound, Antarctica. Microb Ecol 10:231-242

> McMinn A, Skerratt J, Trull T, Ashworth C, Lizotte M (1999a) Nutrient stress gradient in the bottom $5 \mathrm{~cm}$ of fast ice, McMurdo Sound, Antarctica. Polar Biol 21:220-227

> McMinn A, Ashworth C, Ryan KG (1999b) Growth and productivity of Antaractic sea-ice algae under PAR and UV irradiances. Bot Mar 42:401-407

McMinn A, Ashworth C, Ryan KG (2000) In situ net primary 
productivity of an Antarctic fast ice bottom algal community. Aquat Microb Ecol 21:177-185

Meehl GA, Collins WD, Boville BA, Kiehl JT, Wigley TML, Arblaster JM (2000) Response of the NCAR climate system model to increased $\mathrm{CO}_{2}$ and the role of physical processes. J Clim 13:1879-1898

Meiners K, Brinkmeyer R, Granskog MA, Lindfors A (2004) Abundance, size distribution and bacterial colonization of exopolymer particles in Antarctic sea-ice (Bellingshausen Sea). Aquat Microb Ecol 35:283-296

Mock T, Kroon BMA (2002) Photosynthetic energy conversion under extreme conditions. I. Important role of lipids as structural modulators and energy sink under N-limited growth in Antarctic sea-ice diatoms. Phytochemistry 61: 41-51

Mock T, Thomas DN (2005) Recent advances in sea-ice microbiology. Environ Microbiol 7:605-619

Monfort P, Demers S, Levasseur M (2000) Bacterial dynamics in first year sea-ice and underlying seawater of Saroma-ko lagoon (Sea of Okhotsk, Japan) and resolute passage (high Canadian Arctic): inhibitory effects of ice algae on bacterial dynamics. Can J Microbiol 46:623-632

Murray AE, Grzymski JJ (2007) Diversity and genomics of Antarctic marine micro-organisms. Philos Trans R Soc Lond B 362:2259-2271

> Murray AE, Hollibaugh JT, Orrego C (1996) Phylogenetic compositions from two California estuaries by denaturing gradient gel electrophoresis of 16S rDNA fragments. Appl Environ Microbiol 62:2676-2680

Palmisano AC, Sullivan CW (1983) Sea-ice microbial communities (SIMCO). I. Distribution, abundance, and primary production of ice microalgae in McMurdo Sound, Antarctica in 1980. Polar Biol 2:171-177

Pomeroy LR, Wiebe WJ (2001) Temperature and substrates as interactive limiting factors for marine heterotrophic bacteria. Aquat Microb Ecol 23:187-204

Pusceddu A, Dell'Anno A, Vezzulli L, Fabiano M and others (2009) Microbial loop malfunctioning in the annual sea-ice at Terra Nova Bay (Antarctica). Polar Biol 32:337-346

Ralph PJ, Ryan KG, Martin A, Fenton G (2007) Melting out of sea ice causes greater photosynthetic stress in algae than freezing in. J Phycol 43:948-956

Reed HE, Martiny JBH (2007) Testing the functional signifi-

Editorial responsibility: Ronald Kiene,

Mobile, Alabama, USA cance of microbial communities in natural communities. FEMS Microbiol Ecol 62:161-170

Reysenbach AL, Giver LJ, Wickham GS, Pace NR (1992) Differential amplification of rRNA genes by polymerase chain reaction. Appl Environ Microbiol 58:3417-3418

> Rind D, Healy R, Parkinson C, Martinson D (1997) The role of sea-ice in $2 \times \mathrm{CO}_{2}$ climate sensitivity. Part II. Hemispheric dependencies. Geophys Res Lett 24:1491-1494

Ryan KG, McMinn A, Mitchell KA, Trennery L (2002) Mycosporine like amino acids in Antarctic sea-ice algae, and their response to UVB radiation. Z Naturforsch C 57:461-477

Ryan KG, Ralph P, McMinn A (2004) Acclimation of Antarctic bottom-ice algal communities to lowered salinities during melting. Polar Biol 27:679-686

Ryan KG, Hegseth E, Martin A, Davy SK and others (2006) Abundance and distribution of the microalgal community within sea-ice along a latitudinal gradient in the Ross Sea. Antarct Sci 18:583-594

Ryan KG, Cowie ROM, Liggins L, McNaughtan D, Martin A, Davy SK (2009) The short-term effect of irradiance on the photosynthetic properties of Antarctic fast-ice microalgal communities. J Phycol 45:1290-1298

> Sánchez O, Gasol JM, Massana R, Mas J, Pedrós-Alió C (2007) Comparison of different denaturing gradient gel electrophoresis primer sets for the study of marine bacterioplankton communities. Appl Environ Microbiol 73: 5962-5967

Schäfer H, Muyzer G (2001) Denaturing gradient gel electrophoresis in marine microbial ecology. In: Paul J (ed) Methods in microbiology, Vol 30. Marine microbiology. Academic Press, London, p 425-468

Staley JT, Junge K, Deming J (2002) And some like it cold: sea ice microbiology. In: Staley JT, Reysenbach AL (eds) Biodiversity of microbial life. Wiley-Liss, New York, NY, p 423-438

Stewart FJ, Fritsen CH (2004) Bacteria-algae relationships in Antarctic sea-ice. Antarct Sci 16:143-156

> Thomas DN, Dieckmann GS (2002) Antarctic sea-ice: a habitat for extremophiles. Science 295:641-644

Thomas DN, Kattner G, Engbrodt R, Giannelli V, Kennedy H, Haas C, Dieckmann GS (2001) Dissolved organic matter in Antarctic sea-ice. Ann Glaciol 33:297-303

Submitted: May 10, 2010; Accepted: December 2, 2010 Proofs received from author(s): February 15, 2011 